Fitofarmaka, Vol.9, No.1, Juni 2019 ISSN:2087-9164

\title{
AKTIVITAS ANTIBAKTERI LOSION ANTI JERAWAT YANG MENGANDUNG EKSTRAK DAUN BELUNTAS (Pluchea indica (L) Less.)
}

\author{
Ike Yulia Wiendarlina, Dwi Indriati, Mila Rosa \\ Program Studi Farmasi FMIPA Universitas Pakuan Bogor \\ E-mail: yulia21760@gmail.com
}

\begin{abstract}
ABSTRAK
Peradangan jerawat dapat disebabkan oleh bakteri Propionibacterium acnes dan Staphylococcus epidermidis. Bahan alam yang memiliki kemampuan sebagai antibakteri adalah daun beluntas. Daun beluntas mengandung alkaloid, tanin, natrium, minyak atsiri, kalsium, flavonoid, magnesium, fosfor dan asam kolinergik. Penelitian ini menggunakan metode ekstraksi dengan cara maserasi bertingkat yaitu perendaman bahan dengan berbagai jenis pelarut tanpa menggunakan pemanasan. Sediaan losion merupakan kosmetika dengan sistem emulsi minyak dalam air. Pada penelitian ini dibuat sediaan losion antijerawat yang mengandung ekstrak daun beluntas dan diuji aktivitasnya terhadap bakteri Propionibacterium acnes dan Staphylococcus epidermidis dengan menggunakan metode difusi. Penelitian ini meliputi pengujian KHM, LDH sediaan losion dan pengujian fisik pada sediaan losion dengan didasarkan pada formula yang terbaik. Hasil penelitian menunjukkan KHM pada ekstrak etanol daun beluntas konsentrasi $10 \%$ dapat membunuh bakteri penyebab jerawat, Formula terbaik dari hasil pengujian terdapat pada formula 3 karna lebar daerah hambat mendekati hasil dari kontrol positif, Formula 3 merupakan formula yang paling baik dibanding dengan formula yang lainnya.
\end{abstract}

Kata Kunci : Daun Beluntas, Losion anti jerawat, Propionibacterium acnes

\section{ANTIBACTERAL ACTIVITY OF BELUNTAS (Pluchea indica (L) Less.) LEAF EXTRACT ANTI ACNE LOTION}

\begin{abstract}
Inflammation of acne can be caused by the bacteria Propionibacterium acnes and Staphylococcus epidermidis. Natural materials that have the ability as antibacterial is beluntas leaves. Beluntas leaves contain alkaloids, tannins, sodium, essential oils, calcium, flavonoids, magnesium, phosphorus and cholinergic acid. This research uses extraction method by means of multilevel maseration is soaking the material with various types of solvent without using heating. The lotion preparation is cosmetic with an oil-in-water emulsion system. In this research, an anti-acne lotion preparation containing beluntas leaf extract was tested its activity on bacteria Propionibacterium acnes and Staphylococcus epidermidis by using diffusion method. The present study included testing of KHM, LDH of the lotion preparation and physical testing of the lotion preparation based on an existing formula. The results showed KHM on ethanol extract leaves beluntas concentration of $10 \%$ could kill the acne-causing bacteria. The best formula of the test results was found in the 3rd formula because the width of the drag area $(\mathrm{LDH})$ approached the result of positive control, 3rd Formula was the best formula compared to the other formula.
\end{abstract}

Keywords: Beluntas leaf, Anti acne lotion, Propionibacterium acnes 


\section{PENDAHULUAN}

$\begin{array}{lrr}\begin{array}{l}\text { Peradangan } \\ \text { disebabkan }\end{array} & \begin{array}{c}\text { jerawat } \\ \text { oleh }\end{array} & \begin{array}{r}\text { dapat } \\ \text { bakteri }\end{array} \\ \text { Propionibacterium } & \text { acnes } & \text { dan }\end{array}$ Staphylococcus epidermidis. Bakteri ini pada kondisi normal tidak patogen, tetapi bisa menjadi patogen bila terjadi perubahan kondisi kulit yaitu menyebabkan penyumbatan pada saluran kelenjar sebasea yang berperan dalam pembentukan enzim lipolitik pengubah fraksi sebum menjadi massa padat (Radji, 2011).

Bahan alam yang memiliki kemampuan sebagai antibakteri adalah daun beluntas (Pluchea indica (L.) Less). Daun beluntas mengandung alkaloid, tanin, natrium, minyak atsiri, kalsium, flavonoid, magnesium, fosfor dan asam kolinergik (Susetyarini, 2007). Flavonoid dalam daun beluntas memiliki aktivitas antibakteri.Ardiansyah et al., (2003) menyatakan bahwa daun beluntas (Pluchea indica (L.) Less) bersifat antibakteri, terhadap seperti Salmonella typhi, Sthapylococcus aureus, Escherechia coli dan Bacillus cereus.

Penelitian ini menggunakan metode ekstraksi dengan cara maserasi bertingkat yaitu perendaman bahan dengan berbagai jenis pelarut tanpa menggunakan pemanasan. Pemilihan metode maserasi bertingkat bertujuan mengekstraksi seluruh senyawa didalam daun beluntas berdasarkan polaritas pelarut yang digunakan secara umum. Ekstraksi dilakukan secara berturut-turut mulai dari pelarut non polar, semi polar dan polar (Margaretta et al., 2011).

Menurut Mitsui (1997) menyatakan bahwa sediaan losion merupakan kosmetika dengan sistem emulsi minyak dalam air. Losion memiliki kelebihan yaitu kandungan air yang cukup besar dan dapat diaplikasikan dengan mudah, daya penyebaran dan penetrasinya cukup tinggi, tidak memberikan rasa berminyak dan juga mudah dicuci dengan air (Aulton, 2007). Basis formula yang digunakan dalam formulasi losion mengacu pada penelitian Indriati (2014).

Pada penelitian ini dibuat sediaan losion antijerawat yang mengandung ekstrak daun beluntas dan diuji aktivitasnya terhadap bakteri Propionibacterium acnes dan Staphylococcus epidermidis dengan menggunakan metode difusi.

\section{METODE PENELITIAN Alat dan Bahan}

Alat-alat yang digunakan dalam penelitian ini adalah inkubator, oven, autoklaf, gelas piala, gelas ukur, erlenmeyer, labu ukur, pipet tetes, cawan penguap, kaca arloji, corong, botol coklat, kain batis, timbangan digital, spatel, beaker gelas, tabung reaksi, bunsen, ose, cawan petri.

Bahan-bahan yang digunakan pada penelitian ini adalah daun bluntas, bakteri Staphylococcus epidermidis dan Propionibacterium acnes, media agar BHI, Natrium klorida 0,9\% LP, pereaksi Mayer LP, Bouchardat LP, Dragendoff LP, besi klorida $\left(\mathrm{FeCl}_{3}\right) \mathrm{LP}$, etil asetat LP, nheksan LP, etanol 70\% LP, gilserin LP, PEG-40 Hydrogenated Castrol Oil, Caprilic trigliserida, metil paraben, profil paraben, etanol 96\% LP, DMSO

\section{Pengumpulan Bahan dan Determinasi}

Daun beluntas yang digunakan dalam penelitian ini berasal dari desa Nutug Kec. Citereup Kab. Bogor. Determinasi tanaman dilakukan di Lembaga Ilmu Pengetahuan Indonesia (LIPI) Cibinong. Pusat konversi Tumbuhan Kebun Raya, Bogor.

\section{Pembuatan Simplisia Daun Beluntas}

Daun beluntas dikumpulkan sebanyak $5 \mathrm{~kg}$ daun basah. Disortasi basah dibersihkan kemudian dicuci dengan air 
yang mengalir hingga bersih, dan ditiriskan. Setelah kering dilakukan pengeringan didalam oven pada suhu \pm $45^{\circ} \mathrm{C}$, kemudian dilakukan sortasi kering. Simplisia digrinder hingga menjadi simplisia serbuk lalu diayak dengan menggunakan ayakan mesh 60, disimpan dalam wadah yang kering dan bersih, kemudian dihitung presentase rendemennya.

Rendemen Simplisia $=\frac{\text { Bobot Akhir }}{\text { Bobot Awal }} \times 100 \%$

\section{Uji Karakteristik Serbuk Simplisia Daun Beluntas \\ Penetapan Kadar Air}

Penetapan kadar air simplisia dilakukan dengan menggunakan metode gravimetri. Simplisia sebanyak $2 \mathrm{~g}$ dimasukan ke dalam wadah yang telah ditara, keringkan pada suhu $105^{\circ} \mathrm{C}$ selama 5 jam dan timbang, dilanjutkan dengan pengeringan dan ditimbang pada jarak 1 jam sampai perbedaan antara 2 penimbangan berturut-turut tidak lebih dari 0,025\% (DepKes RI, 2000).

\section{Penetapan Kadar Abu}

Simplisia daun beluntas sebanyak 2 $\mathrm{g}$ ditimbang dan dimasukan ke dalam krus platina atau krus silikat yang telah dipijarkan dan ditara, diratakan. Simplisia dipijarkan perlahan-lahan hingga arang habis, didinginkan lalu ditimbang. Hitung kadar abu terhadap bahan yang telah dikeringkan di udara. Syarat kadar abu untuk simplisia daun beluntas tidak lebih dari 9\% (DepKes RI, 2000).

$$
\text { Kadar Abu }=\frac{\text { Bobot abu }}{\text { Bobot simplisia }} \times 100 \%
$$

\section{Pembuatan Ekstrak Daun Beluntas}

Ekstrak dilakukan dengan cara maserasi bertingkat sebanyak $500 \mathrm{~g}$ serbuk kering simplisia. Pelarut yang digunakan adalah pelarut dengan kepolaran yang meningkat yaitu n-heksan (non polar), etil asetat (semi polar), dan etanol $70 \% \quad$ (polar). Pelarut yang digunakan masing-masing sebanyak 2500 $\mathrm{mL}(2: 10)$. Maserat dari masingmasing pelarut $n$-heksan, etil asetat, etanol $70 \%$ dikumpulkan kemudian diuapkan dengan rotary evaporator hingga diperoleh ekstrak kental. Rendemen dihitung masing-masing ekstrak yang diperoleh yaitu presentase bobot $(b / b)$ antara rendemen dengan bobot serbuk simplisia yang digunakan dengan penimbangan.

\section{Uji Fitokimia Ekstrak Daun Beluntas Uji Flavonoid}

Sebanyak $0,5 \mathrm{~g}$ ekstrak dilarutkan dalam $5 \mathrm{~mL}$ etanol $96 \%$. Larutan sampel diambil $2 \mathrm{~mL}$, ditambahkan sedikit $0,1 \mathrm{~g}$ serbuk $\mathrm{Mg}$ dan ditambahkan 10 tetes $\mathrm{HCl}$ $P$ dari sisi tabung serta dikocok perlahanlahan. Warna merah atau jingga yang terbentuk menunjukan adanya flavonoid, jika terjadi warna kuning jingga menunjukan adanya flavon, kalkon, dan auron (Hanani, 2015)

\section{Uji Alkaloid}

Sebanyak 0,5 g ekstrak dilarutkan dengan melarutkan dalam beberapa asam sulfat $2 \mathrm{~N}$ kemudian diuji dengan 2 pereaksi alkaloid yaitu pereaksi dragendorff dan pereaksi Mayer hasil positif diperoleh bila terbentuk endapan merah hingga jingga dengan pereaksi Dragendorff dan endapan putih kekuningan dengan pereaksi Mayer (Hanani, 2015).

\section{Uji Tanin}

Sebanyak 2 g ekstrak diekstraksi dengan etanol $70 \%(30 \mathrm{~mL})$ selama 15 menit, kemudian disaring. Filtrat yang didapat diuapkan diatas penangas. Aquadest panas sisa penguapan ditambahkan lalu diaduk, setelah dingin larutan di sentrifugasi. Cairan atas dipisahkan dengan cara dekantasi dan filtrat digunakan sebagai larutan 
percobaan yang akan digunakan dalam pengujian berikut :

a. Fitrat ditambahkan larutan 10\% gelatin, akan timbul endapan putih.

b. Filtrat ditambahkan $\mathrm{NaCl}$ - gelatin ( larutan $1 \%$ gelatin dalam $10 \% \mathrm{NaCl}$ dengan perbandingan 1:1). Timbul endapan dibandingkan dengan hasil pada butir 1 .

c. Filtrat ditambahkan larutan $3 \% \mathrm{FeCl}_{3}$ terjadi warna hijau biru hingga kehitaman. (Hanani, 2015).

\section{Uji Saponin}

Sebanyak 0,5 g ekstrak dilakukan dengan aquadest lalu dipanaskan di atas penangas air, setelah dingin larutan dalam tabung reaksi dikocok kuat-kuat selama \pm 30 detik. Hasil positif yaitu terbentuknya busa yang konsisten selama beberapa menit dengan penambahan tetes $\mathrm{HCl}$ encer masih terbentuk busa (DepKes RI, 1989).

\section{Pengujian Aktivitas Ekstrak Daun Beluntas Penyiapan Media}

Serbuk BHI sebanyak $40 \quad \mathrm{~g}$ dilarutkan dalam $1000 \mathrm{~mL}$ air akuades dan dipanaskan hingga mendidih selama 10-15 menit sampai terbentuk larutan homogen. Larutan disterilkan dalam autoklaf pada suhu $121^{\circ} \mathrm{C}$ selama 15 menit dengan tekanan 1 atm sebelum media digunakan. Pembuatan media untuk kultur stok dilakukan dengan cara menuangkan $5 \mathrm{~mL}$ media yang masih cair ke dalam cawan Petri steril secara aseptis, setelah mengeras media diinkubasi selama 24 jam pada $35-37^{\circ} \mathrm{C}$ (Larassaty, 2008).

\section{Penentuan Konsentrasi Hambat Minimum (KHM)}

Konsentrasi hambat minimum (KHM) dapat ditentukan dengan metode dilusi. Prinsip metode dilusi adalah menggunakan satu seri cawan Petri yang diisi medium cair dan sejumlah bakteri yang akan diuji. Penyiapan ekstrak terlebih dahulu dibuat larutan stok dengan konsentrasi ekstrak 40\% dalam $100 \mathrm{~mL}$ DMSO, kemudian dibuat pengenceran hingga didapat konsentrasi ekstrak 5\%, $10 \%, 20 \%$.

Sampel larutan uji yang telah disiapkan dari ekstrak daun beluntas dengan konsentrasi $5 \% ; 10 \% ; 20 \%$ masing-masing diambil $1 \mathrm{~mL}$ dan $0,2 \mathrm{~mL}$ bakteri uji dimasukkan ke dalam cawan Petri yang telah berisi media kemudian digoreskan secara zig zag dan dibiarkan sampai mengeras diinkubasi selama 24 jam pada suhu $35^{0}-37^{0} \mathrm{C}$, dilihat dan diamati adanya pertumbuhan bakteri atau tidak. Konsentrasi dari ekstrak daun beluntas yang tidak terjadi pertumbuhan bakteri pada cawan Petri merupakan konsentrasi hambat minimum (KHM).

\section{Formula dan Cara Pembuatan Losion Antijerawat}

Formulasi pembuatan losion antijerawat ekstrak daun beluntas dibuat dengan formulasi ekstrak daun beluntas yang berbeda-beda yaitu pada konsentrasi $10 \%, 15 \%$, dan $20 \%$ yang merupakan hasil uji KHM. Formulasi basis losion mengacu pada penelitian Indriati (2014). Formulasi ini dapat dilihat pada table 1. 
Tabel 1. Formula sediaan Losion ekstrak daun beluntas

\begin{tabular}{lcccc}
\hline & \multicolumn{4}{c}{ Konsentrasi (\%) } \\
Bahan & Basis & Formula I & Formula II & Formula III \\
\hline Ekstrak daun beluntas & - & 10 & 15 & 20 \\
Caprilic trigliserida & 5 & 5 & 5 & 5 \\
PEG-40 Hydrogenated & & & & \\
Castrol Oil & 24,5 & 24,5 & 24,5 & 24,5 \\
Etanol & & & & \\
Gliserin & 5,25 & 5,25 & 5,25 & 5,25 \\
Metil paraben, & 5,25 & 5,25 & 5,25 & 5,25 \\
Propil Paraben & 0,18 & 0,18 & 0,18 & 0,18 \\
Akuades Add & 0,02 & 0,02 & 0,02 & 0,02 \\
\hline \multicolumn{1}{c}{ Sumer } & 100 & 100 & 100 & 100 \\
\hline
\end{tabular}

Sumber: Indriati, 2014

Formula losion antijerawat ekstrak daun beluntas dibuat berupa emulsi minyak dalam air. Fase minyak PEG-40 Hydrogenated Castrol Oil dan Caprilic trigliserida dilebur di atas penangas air pada suhu $50^{\circ} \mathrm{C}$. Fase air metil paraben, propil paraben dan gliserin, ditambahkan akuades lalu dipanaskan di atas penangas air pada suhu $50^{\circ} \mathrm{C}$. Fase minyak dan fase air dicampurkan, kemudian dihomogenkan dengan homogenizer pada kecepatan $500 \mathrm{rpm}$ pengadukan selama 15 menit, etanol dimasukkan sedikit demi sedikit setelah suhu menurun. Pengadukan dilakukan hingga terbentuk basis yang diinginkan, setelah homogen ekstrak daun beluntas dicampurkan lalu diaduk kembali sampai homogen.

\section{Evaluasi Losion Antijerawat Ekstrak Daun Beluntas \\ Uji LDH Losion Antijerawat Ekstrak Daun Beluntas}

Pengujian ini dilakukan dengan metode difusi agar dengan menggunakan kertas cakram. Pada metode ini dilihat daerah atau zona bening yang dihasilkan kertas cakram. Konsentrasi yang diuji aktifitas dengan berbagai konsentrasi larutan kontrol positif yaitu acnol dan larutan negatif yaitu akuades.
Kertas cakram berbentuk lingkaran dengan diameter $\pm 6 \mathrm{~mm}$ dicelupkan dan ditetesi larutan yaitu akuades sebagai kontrol negatif, acnol sebagai kontrol positif dan sediaan losion dengan konsentrasi hasil KHM masing-masing sebanyak $1 \mathrm{~mL}$, selanjutnya dimasukan dalam oven dengan suhu $40^{\circ} \mathrm{C}$ selama 24 jam. Inokulum bakteri dari hasil pengenceran disatukan pada media, masing-masing dituang ke cawan kosong sebanyak $15 \mathrm{~mL}$ kemudian diinkubasi selama 1 jam sampai agar memadat kemudian kertas cakram yang sudah berisi larutan uji dan kontrol diletakan diatas media agar, disimpan dalam inkubator selama 24 jam pada suhu $25^{\circ} \mathrm{C}$, setelah diinkubasi diamati disekeliling kertas cakram pada masing masing konsentrasi diukur Lebar Daerah Hambat (LDH) yang terbentuk. Pengujian ini dilakukan untuk masing-masing konsentrasi losion ekstrak dengan 2 kali pengulangan.

Cara perhitungan :

$\mathrm{LDH}=\frac{(D D H-D i s k)}{2}$

Keterangan:

LDH : Lebar Daerah Hambat

DDH : Diameter Daya Hambat $(\mathrm{cm})$

Disk : Ukuran kertas saring $(\mathrm{cm})$ 


\section{Pemeriksaan Organoleptik}

Uji organoleptik adalah pengujian yang dilakukan berdasarkan pada proses penginderaan. Pengujiaan organoleptik sediaan losion meliputi warna, bentuk dan aroma sediaan (Rowe et al., 2009).

\section{Uji pH}

Uji pH dilakukan untuk melihat keasaman sediaan losion untuk menjamin sediaan losion tidak mengiritasi kulit. $\mathrm{pH}$ sediaan losion diukur dengan menggunakan $\mathrm{pH}$ meter. $\mathrm{pH}$ meter dicelupkan ke dalam sampel losion, diamkan beberapa saat dan hasilnya disesuaikan dengan standar $\mathrm{pH}$ meter. Sediaan yang memenuhi kriteria $\mathrm{pH}$ kulit yaitu dalam interval 4,5 - 7,5 (Rowe et al., 2009).

\section{Uji Homogenitas}

Uji homogenitas ditentukan dengan cara losion dioleskan pada kaca arloji atau bahan transparan lainnya yang cocok harus menunjukkan susunan yang homogen dan tidak adanya partikelpartikel kasar pada permukaan kaca transparan (DepKes, 1979).

\section{Viskositas}

Penentuan viskositas bertujuan untuk mengetahui adanya perbedaan kekentalan pada tiap formula losion. Viskositas dilakukan dengan cara mengamati angka pada skla viskometer Brookfield dengan kecepatan dan waktu tertentu. Losion diletakkan pada wadah berupa tabung silinder kaca atau gelas piala lalu dipasangkan spindel pada tuasnya kemudian spindel diputar dengan kecepatan tertentu sampai viskometer menunjukkan pada skala yang konstan (Rowe et al., 2009).

\section{Hasil dan Pembahasan \\ Hasil Determinasi}

Hasil determinasi menyatakan bahwa tanaman yang digunakan dalam penelitian ini adalah daun beluntas dengan nama latin Pluchea indica (L.) Less. suku Compositae.

\section{Hasil Simplisia Daun Beluntas}

Daun beluntas digunakan sebanyak $5000 \mathrm{~g}$ diperoleh serbuk simplisia sebanyak $1765 \mathrm{~g}$ (Rendemen 64,7\%) daun beluntas memiliki karakteristik serbuk simplisia berwarna hijau tua kekuningan, memiliki rasa kelat dan aroma yang kuat.

\section{Hasil kadar air dan kadar abu}

Hasil pengujian pada Tabel 2 diperoleh kadar air serbuk simplisia daun beluntas yaitu sebesar $4,582 \%$, hal ini menunjukkan bahwa serbuk simplisia memenuhi persyaratan yaitu tidak lebih dari 5\%, sedangkan pada ekstrak n-heksan diperoleh 4,08\%, ekstrak etil asetat diperoleh 3,735\% dan ekstrak etanol 70\% diperoleh 5,29\% hasil memenuhi persyaratan tidak lebih dari 9,54\%.

Tabel 2. Hasil Pengujian Kadar Air dan Kadar Abu Simplisia

\begin{tabular}{ccc}
\hline Simplisia/Ekstrak & $\begin{array}{c}\text { Kadar } \\
\text { Air } \\
\text { Rata- } \\
\text { rata }\end{array}$ & $\begin{array}{c}\text { Kadar } \\
\text { Abu } \\
\text { Rata- } \\
\text { rata }\end{array}$ \\
\hline Daun beluntas & $4,58 \%$ & $6,33 \%$ \\
Ekstrak n heksan & $4,08 \%$ & $6,30 \%$ \\
Ekstrak etil asetat & $3,73 \%$ & $4,03 \%$ \\
Ekstrak etanol 70\% & $5,29 \%$ & $8,34 \%$ \\
\hline
\end{tabular}

Serbuk simplisia daun beluntas didapat hasil kadar abu sebesar 6,3305\% hasil tersebut memenuhi persyaratan yaitu tidak lebih dari 9\% serta hasil dari ekstrak n heksan diperoleh 6,303\%, ekstrak etil asetat diperoleh $4,03 \%$ dan etanol $70 \%$ diperoleh $8,34 \%$ hasil memenuhi persyaratan yaitu tidak lebih dari $25,92 \%$ (DepKes RI 1995). 
Hasil Pembuatan Ekstrak Daun
Beluntas

Tabel 3. Hasil Rendemen Ekstrak Daun

Beluntas

\begin{tabular}{ccc}
\hline Bahan & Ekstrak & $\begin{array}{c}\text { Rendemen } \\
(\%)\end{array}$ \\
\hline \multirow{3}{*}{ Daun } & n-heksan & $5,69 \%$ \\
Eeluntas & Etanol 70\% & $2,30 \%$ \\
& & $12,41 \%$ \\
\hline
\end{tabular}

Rendemen dari Tabel 3 menunjukkan masing-masing ekstrak kental berpengaruh terhadap senyawa aktif yang terekstraksi. Pelarut polar akan menarik senyawa yang bersifat polar, sedangkan pelarut non polar akan menarik senyawa non polar dan pelarut semi polar akan menarik senyawa polar (DepKes RI, 1986).

\section{Hasil Uji Fitokimia Ekstrak Kental Daun Beluntas}

Tabel 4. Kandungan Senyawa Ekstrak Daun Beluntas

\begin{tabular}{ccccc}
\hline Sampel & \multicolumn{4}{c}{ Parameter Uji } \\
\cline { 2 - 5 } & Flavonoid & Alkaloid & Saponin & Tanin \\
\hline Ekstrak n-heksan & - & - & + & + \\
Ekstrak etil asetat & + & + & + & + \\
Ekstrak etanol 70\% & + & + & + & + \\
\hline Keterangan : & (+) Mengandung senyawa & (-) Tidak mengandung \\
fitokimia & senyawa fitokimia
\end{tabular}

\section{Hasil Pengujian Aktivitas Antibakteri Ekstrak Daun Beluntas}

Media yang diujikan pada bakteri Staphylococcus epidermidis yang mengandung ekstrak n-heksan daun beluntas pada konsentrasi $20 \%$ tidak terlihat adanya pertumbuhan bakteri, berbeda dengan konsentrasi 5\% dan 10\% masih terlihat adanya pertumbuhan bakteri.

Ekstrak etil asetat dengan konsentrasi $5 \%$, 10\%, dan $20 \%$ masih terlihat adanya pertumbuhan bakteri pada media, sedangkan pada ekstrak etanol 70\% pada konsentrasi $5 \%, 10 \%$ bakteri masih tumbuh dan pada konsentrasi $20 \%$ terlihat tidak adanya pertumbuhan bakteri.

Bakteri Propionibacterium acne yang diujikan pada media ekstrak $\mathrm{n}$ heksan daun beluntas pada konsentrasi 5\%, 10\% dan $20 \%$ masih terlihat adanya pertumbuhan bakteri dan ekstrak etil asetat daun beluntas pada konsentrasi 5\%, 10\%,20\% masih adanya pertumbuhan. bakteri sedangkan ekstrak etanol $70 \%$ pada konsentrasi $5 \%$ masih adanya pertumbuhan bakteri berbeda dengan konsentrasi $10 \%$ dan $20 \%$ tidak terlihatnya adanya pertumbuhan bakteri artinya sudah menunjukkan adanya hambatan pertumbuhan bakteri.

Konsentrasi Hambat Minimum (KHM) untuk pembuatan sediaan losion anti jerawat diambil dari ekstrak etanol $70 \%$ dengan konsentrasi $10 \%$ dan pada penelitian terdahulu oleh Sulistiyaningsih (2009), hasil uji aktifitas antibakteri ekstrak etanol 96\% daun beluntas terhadap Methicillin Resistant Staphylococcus aureus (KHM 25\%) dan Pseudomonas aeruginosa Multi Resistant (KHM 52\%).

Hasil ini menunjukkan bahwa ekstrak etanol $70 \%$ daun beluntas berpotensi sebagai antibakteri terhadap Sthaphylococcus epidermidis dan Propionibacterium acnes. Ekstrak etanol $70 \%$ senyawa yang memiliki peran sebagai antibakteri adalah flavonoid 
karena tingkat kepolaran yang tinggi dari senyawa flavonoid maka akan dengan mudah menembus dinding sel dari bakteri Staphylococcus epidermidis dan Propionibacterium acnes.

\section{Hasil Pembuatan Losion Ekstrak Daun Beluntas}

Sediaan losion ekstrak daun beluntas dibuat dengan menambahkan variasi konsentrasi ekstrak daun beluntas sesuai hasil uji KHM ekstrak yaitu pada konsentrasi $0 \% \quad$ (basis), $\quad 10 \% \quad$ (F1), $15 \%(\mathrm{~F} 2), 20 \%(\mathrm{~F} 3)$. Hasil dari keempat formula yang dibuat menunjukkan adanya hubungan antara konsentrasi ekstrak dengan warna sediaan maka makin tinggi konsentrasi ekstrak maka warna dari sediaan makin pekat.

\section{Pengujian Konsentrasi Hambat Minimum (KHM)}

Tabel. 5. Hasil Pengujian KHM

\begin{tabular}{ccccc}
\hline \multirow{2}{*}{ Bakteri } & \multirow{2}{*}{ Ekstrak } & \multicolumn{3}{c}{ Konsentrasi } \\
& & $5 \%$ & $10 \%$ & $20 \%$ \\
\hline Staphylococcus epidermidis & Ekstrak n heksan & $\sqrt{ }$ & $\sqrt{ }$ & - \\
& Ekstrak etil asetat & $\sqrt{ }$ & $\sqrt{ }$ & $\sqrt{ }$ \\
& Ekstrak etanol 70\% & $\sqrt{ }$ & $\sqrt{ }$ & - \\
Propionibacterium acne & Ekstrak n heksan & $\sqrt{ }$ & $\sqrt{ }$ & $\sqrt{ }$ \\
& Ekstrak etil asetat & $\sqrt{ }$ & $\sqrt{ }$ & $\sqrt{ }$ \\
& Ekstrak etanol 70\% & $\sqrt{ }$ & - & - \\
\hline
\end{tabular}

Keterangan: $\sqrt{ }=$ Bakteri Masih Tumbuh - : Bakteri Tidak Tumbuh

\section{Hasil Evaluasi Losion Ekstrak Daun Beluntas}

Hasil Uji LDH Losion Ekstrak Daun Beluntas

Formula 1 yang diujikan pada bakteri Stapylococcus epidermidis dengan konsentrasi $10 \%$ rata-rata zona hambat yang didapat $3,5 \mathrm{~mm}$, formula 2 konsentrasi $15 \%$ adalah $4,5 \mathrm{~mm}$ dan formula 3 konsentrasi $20 \%$ adalah 6,25 mm, sedangkan pada bakteri Propionibacterium acnes pada formula 1 konsentrasi $10 \%$ didapat $4 \mathrm{~mm}$, formula 2 konsentrasi $15 \%$ adalah $5,25 \mathrm{~mm}$ dan formula 3 konsentrasi $20 \%$ adalah 6,5 $\mathrm{mm}$. Kontrol positif yang digunakan losion acnol didapat $8 \mathrm{~mm}$ terhadap Stapylococcus epidermidis dan 9,5 mm terhadap Propionibacterium acnes terlihat bahwa pada losion acnol zona hambat yang terukur lebih besar dibandingkan dengan formula ekstrak daun beluntas.

Tabel 6. Hasil Uji LDH Sediaan Losion Antijerawat Ekstrak Daun Beluntas

\begin{tabular}{llcc}
\hline \multicolumn{1}{c}{ Bakteri } & Formula & Konsentrasi & $\begin{array}{c}\text { LDH } \\
(\mathrm{mm})\end{array}$ \\
\hline $\begin{array}{llcc}\text { Staphylococcus } \\
\text { epidermidis }\end{array}$ & Formula 1 & $10 \%$ & 3,5 \\
& Formula 2 & $15 \%$ & 4,5 \\
& Formula 3 & $20 \%$ & 6,25 \\
& Basis & 0 & 0 \\
& Kontrol (+) & 0 & 8 \\
Propionibacterium & Kontrol (-) & 0 & 0 \\
acne & Formula 1 & $10 \%$ & 4 \\
& Formula 2 & $15 \%$ & 5,25 \\
& Formula 3 & $20 \%$ & 6,5
\end{tabular}




\begin{tabular}{llc} 
Basis & 0 & 0 \\
Kontrol (+) & 0 & 9,5 \\
Kontrol (-) & 0 & 0 \\
\hline
\end{tabular}

Losion acnol mengandung antibakteri spektrum luas yaitu mampu menghambat pertumbuhan bakteri gram positif dan negatif yang peka. Formula terbaik dari hasil pengujian terdapat pada formula 3 karna lebar daerah hambat mendekati hasil dari kontrol positif.

Uji Evaluasi Fisik Formula Terbaik

Tabel 7. Uji Evaluasi Fisik Formula Terbaik

\begin{tabular}{|c|c|c|}
\hline \multirow{2}{*}{ Parameter Uji } & \multicolumn{2}{|c|}{ Formula } \\
\hline & F3 & Syarat \\
\hline Uji & & \\
\hline Organoleptik & & - \\
\hline Warna & $\begin{array}{l}\text { Hijau } \\
\text { Pekat }\end{array}$ & \\
\hline Aroma & Khas & - \\
\hline Bentuk & Cair & Cair \\
\hline Viskositas (cPs) & $443 \mathrm{cPs}$ & $20-500 \mathrm{cPs}$ \\
\hline Homogenitas & Homogen & Homogen \\
\hline $\begin{array}{l}\text { Derajat } \\
\text { Keasaman }(\mathrm{pH})\end{array}$ & 7 & $4,5-7,5$ \\
\hline
\end{tabular}

Hasil dari pengujian diperoleh aroma losion yang berbau khas, warna yang dihasilkan dari losion antijerawat yaitu hijau pekat, bentuk yang dihasilkan dalam bentuk cair.

Kulit wajah memiliki $\mathrm{pH}$ 4,5- 7,5 hasil pengujian $\mathrm{pH}$ losion didapat 7 yang berarti bahwa $\mathrm{pH}$ losion antijerawat ekstrak daun beluntas masih berada dalam kisaran $\mathrm{pH}$ kulit wajah sehingga dapat aman digunakan.

Menurut DepKes RI, yang dikutip oleh Agustin et al. (2013), losion yang baik harus menunjukan susunan yang homogen dan tidak terlihat bintik-bintik. Hasil penelitian yang dilakukan menunjukan tidak adanya granul atau bintik pada objek glas.

Hasil pengujian viskositas didapat $443 \mathrm{cp}$, hasil dari penelitian yang telah dilakukan hasil memenuhi persyaratan standar viskositas losion. Syarat viskositas losion menurut SNI 16-4399-1996 yaitu antara 20-500 poice.

\section{SIMPULAN}

1. Ekstrak daun beluntas memiliki aktivitas antibakteri terhadap bakteri dengan Konsentrasi Hambat minimum (KHM) $10 \%$ dan ekstrak daun beluntas dapat dibuat sediaan losion yang memiliki aktivitas antibakteri terhadap bakteri jerawat.

2. Formula 3 sediaan losion antijerawat dengan penambahan ekstrak daun beluntas $20 \%$ merupakan formula yang paling baik dibanding dengan formula yang lainnya.

\section{SARAN}

1. Perlu dilakukannya metode ekstraksi lain pada daun beluntas untuk menghasilkan sediaan losion antijerawat dengan tampilan dan warna yang lebih menarik.

2. Perlu dilakukan pengujian stabilita untuk mengetahui daya simpan dari sediaan losion antijerawat ekstrak daun beluntas

\section{DAFTAR PUSTAKA}

Agustin, R. Y. Oktadefitri, H. Lucida. 2013. Formulasi krim tabir surya dari kombinasi etil p-metoksinamat dengan katekin. Prosiding Seminar Nasional Perkembangan Terkini Sains Farmasi dan Klinik III. 184198.

Ardiansyah, A., L. Nuraida, N. Andarwulan, N. 2003. Aktivitas antimikroba daun beluntas (Pluchea indica Less) dan stabilitas aktivitasnya pada berbagai 
konsentrasi garam dan tingkat $\mathrm{pH}$. Jurnal Teknologi dan Industri Pangan. 14(2): 90-97.

Aulton, M.E. 2007. Pharmaceutics The Design and Manufacture of Medicines, Third Edition. Edinburgh London New York Oxford Philadelphia ST Louis Sydney Toronto.

DepKes RI. 1979. Farmakope Indonesia. Edisi Ketiga. Jakarta.

DepKes RI.1985. Tanaman Obat Indonesia, Jilid 1. Jakarta. 9.

DepKes RI. 2000. Parameter Standar Umum Tumbuhan Obat. Ditjen POM. Jakarta. 9-11, 16

Hanani, E. 2015. Analisis Fitokimia. ECG. Jakarta. Hal: 86-87

Indriati, D. 2014. Formulasi dan uji efektivitas losion ekstrak daun mangkokan (Nothopanax scutellarium Merr) dan Herba Seledri (Apium graviolens Linn) terhadap laju pertumbuhan rambut kelinci. Tesis. Program Magister Ilmu Kefarmasian Universitas Pancasila. Jakarta.

Larassaty, D. 2008. Uji aktifitas ekstrak etanol buah adas (Foeniculum vulgare Miller) dalam menghambat Pertumbuhan Staphylococcus aurens dan Escherichia coli. Skripsi. Universitas Pakuan. Bogor
Margaretta, S., D. Handayani, N. Indraswati, H. Hindarso. 2011. Ekstraksi senyawa phenolic Pandanus amaryllifolius Roxb. Jurnal Widya Teknik. 10 (1): 21-30.

Mitsui, T. 1997. New Cosmetic Science. Elsevier Inc. Amsterdam.

Radji, M. 2011. Buku Ajaran Mikrobiologi Panduan Mahasiswa Farmasi dan Kedokteran. Buku Kedokteran EGC. Jakarta.

Rowe, R.C., P.J. Sheskey, M.E Quinn. 2009. Handbook of Pharmacetical Excipients. Lexi-Comp: American Pharmacetical Association, Inc. New York.

SNI 16-4399-1996. 1996. Sediaan Tabir Surya. Badan Standarisasi Nasional. Jakarta.

Sulistiyaningsih, R. 2009. Potensi Daun Beluntas (Pluchea Indica Less.) Sebagai Inhibitor Terhadap Pseudomonas aeruginosa Multi Resistant Dan Methicillin Resistant Stapylococcus aureus. Penelitian Mandiri. Universitas Padjadjaran, Bandung.

Susetyarini, R.E. 2007. Efek senyawa aktif daun beluntas (Pluchea indica Less) terhadap kadar testoteron tikus putih (Ratus norwegicus) jantan. Jurnal Gamma. 5(1): 21-27. 